\title{
Reforming Fiscal Responsibility Legislation
}

\author{
Stephen Kirchner ${ }^{1}$
}

\begin{abstract}
Monetary and fiscal rules are complementary. Whereas monetary policy and monetary institutions have been reformed in line with developments in modern macroeconomics, fiscal policies and institutions have not kept pace with these developments. Murray's (2008) review of Australia's existing fiscal responsibility legislation, the Charter of Budget Honesty, has pointed out significant shortcomings. This paper outlines a proposal by Carling and Kirchner (2009) to reform Australia's fiscal responsibility legislation. It proposes three fiscal policy rules that are designed primarily to tie-down expectations in relation to the long-run path of the Commonwealth government's net debt. It also proposes the establishment of an independent Fiscal Commission to monitor and enforce compliance with the rules and to improve the transparency, independence and accountability of the federal budget process. The proposal aims to give politicians the commitment technology they need to address the fiscal challenges posed by an aging population and innovations in the terms of trade.
\end{abstract}

Keywords: fiscal responsibility legislation, fiscal rules.

Monetary and fiscal policy rules are complementary, not least because the various versions of the fiscal theory of the price level suggest that, under certain conditions, the fiscal authority can dominate the monetary authority in the determination of the price level (Kocherlakota and Phelan, 1999). Fiscal policy that does not heed the government's inter-temporal budget constraint can subvert even a well-designed monetary regime, thereby destabilising long-run inflation expectations and leading to increased macroeconomic instability. Fiscal policy rules may also be useful in addressing the common pool externality and principal-agent problems that give rise to an excessive government spending and budget deficit bias (von Hagen and Harden, 1995). This is analogous to the role of monetary policy rules and increased central bank independence and transparency in addressing the inflation bias in monetary policy.

Inflation and other macroeconomic outcomes have been shown to be sensitive to the choice of monetary policy rules and monetary institutions (Cukierman, 1992; Clarida et al., 1998, 2000). Similarly, fiscal outcomes have been shown to be sensitive to the choice of fiscal institutions, budgetary procedures and fiscal policy rules in a variety of settings (see, e.g. the papers collected in Poterba and von Hagen, 1999; von Hagen, 2002).

Central banking institutions and monetary policy practice in Australia and elsewhere now closely reflect the New Keynesian orthodoxy in macroeconomics, including a commitment to rules-based monetary policy (Clarida et al., 1999). In contrast, the conduct of fiscal policy and the development of fiscal institutions have not kept pace with modern macroeconomic thinking (Leeper, 2010).

Former Senator Andrew Murray's (2008) review of the Charter of Budget Honesty Act 1998 as part of the Rudd government's "Operation Sunlight" reforms highlighted many of the shortcomings of

${ }^{1}$ University of Technology Sydney Business School and Centre for Independent Studies

JEL classifications: H61, H62, H63, H68

Correspondence: Stephen Kirchner, Economics Group, University of Technology Sydney Business School, PO Box 123, Broadway NSW 2007, Australia. Email: stephen.kirchner@uts.edu.au 
Australia's existing fiscal responsibility legislation. The Charter only requires governments to pay lip service to principles of fiscal soundness, but is otherwise non-prescriptive about fiscal policy outcomes. The Charter explicitly precludes any form of administrative or judicial review that would make its provisions enforceable.

The literature suggests the following requirements for effective fiscal policy rules: "the fiscal target must be clear-cut and comprehensive, enforcement should rely on independent agents, and the formal restraints involved should be difficult to amend" (von Hagen and Strauch, 2001, p. 20). Carling and Kirchner (2009) make the case for reforming Australia's existing federal fiscal responsibility legislation based on these criteria and consistent with Leeper's (2010) call for fiscal institutions to be reformed to reflect developments in modern macroeconomics, just as central banking institutions have been reformed since the early 1990s.

An important potential benefit of a rules-based approach to monetary policy is to stabilise expectations in relation to the long-run price level. Fiscal policy rules can perform a similar function in relation to expectations for the future path of fiscal variables such as the net debt burden. Just as the expected path of the real official interest rate is more important to the stance of monetary policy than the actual interest rate, the expected future path of fiscal policy variables is just as important as ex post fiscal policy outcomes. As Leeper (2009, p. 12) notes, "consumption-saving decisions are influenced, not by the current tax rate on saving, but by the expected tax rate because it is the tax rate in the future that affects the expected return to saving."

Many of the debates about fiscal policy in Australia, including the effectiveness of fiscal stimulus and election policy costings are second- and third-order issues compared with the institutional framework in which fiscal policy is conducted and its role in conditioning expectations for future fiscal outcomes. The case for fiscal policy rules has typically been motivated by concerns over deficit spending and growing debt burdens. However, in the Australian context, an equally valid concern has been whether fiscal policy before the 2007-2008 financial crisis, at least on an ex post basis, was too tight. With pre-crisis budget surpluses in excess of 2 per cent of gross domestic product (GDP; inclusive of Future Fund earnings) and with Commonwealth net debt having been eliminated in 2004-2005, the federal government found that the management of large budget surpluses raises just as many issues as large deficits (Kirchner, 2006). A discretionary fiscal policy designed to lift national saving by increasing public sector saving is no more likely to succeed than a discretionary fiscal policy designed to boost aggregate demand because of offsetting private sector responses (Kirchner, 2007).

Some may see it as a sign of fiscal prudence that the Commonwealth should run large budget surpluses and accumulate a positive net asset position. However, as with any other type of saving, public saving is just deferred spending and we have no reason to expect that future governments will spend today's saving any more wisely than they do currently. If we think governments today make poor spending decisions, why would we expect future governments to behave any differently in the absence of specific changes in incentives? The dynamic inconsistency problem that drives the case for monetary policy pre-commitment is relevant in this context, because the accumulation of a large Commonwealth net asset position could create incentives for fiscal irresponsibility in the future in the absence of improved fiscal responsibility legislation. Even where politicians recognise the government's inter-temporal budget constraint, they currently lack an appropriate commitment technology that would enable them to make time-consistent fiscal policy choices. The Carling-Kirchner proposal to reform Australia's fiscal responsibility legislation aims to give politicians the technology they need to make these choices.

The 2010 Australian federal election outcome has seen renewed impetus for reform in this area, which seems to have coalesced around the idea of an independent parliamentary budget office, although the role and scope of this institution have not been defined at the time of writing. A new Office for Budget Responsibility has also been established by the Conservative-led coalition government in the United Kingdom, while a similar institution is in place in Canada (Fleming, 2010). The US Congressional Budget Office ( $\mathrm{CBO}$ ) has also been suggested as a model for Australia, but the $\mathrm{CBO}$ is designed for a different system of government in which the legislature rather than the 
executive plays the larger role in formulating the budget. Whatever might be said for the CBO, fiscal policy outcomes in the United States have been disastrous, not least because the legislature is allowed too great a role in formulating the budget.

While visiting the Reserve Bank of New Zealand, Larry Ball (1996) proposed a Macroeconomic Policy Committee that would assume responsibility for the discretionary component of both monetary and fiscal policy. This was an idea picked-up locally by Nicholas Gruen (1997) in his proposal for the Business Council of Australia. The Ball approach is mainly concerned with relocating the responsibility for running short-term discretionary demand management, whereas the CarlingKirchner approach is partly predicated on the view that short-term demand management is the wrong focus for fiscal policy and is likely to be ineffective in an institutional environment in which expectations are not well managed.

Carling and Kirchner propose an independent statutory Fiscal Commission, with Commissioners appointed in consultation with the states, much like the Australian Competition and Consumer Commission Commissioners. The role of the Commission would include defining the parameters for the annual budget and other fiscal policy statements, including the economic forecasts and fiscal projections, as well as producing analytical reports such as Intergenerational Reports and policy costings.

The federal government would formulate its budget within the parameters defined by the Commission, but also subject to legislated fiscal rules the Commission would monitor and enforce. The federal government would still enjoy substantial discretion to make tax and spending decisions within this overall framework, but the framework would serve to tie down expectations in relation to long-run fiscal outcomes, while also taking some of the politics out of key elements of the budget process.

Before describing the fiscal policy rules, it is important to emphasise that we see these being made subject to well-defined caveats such as those contained in the Reserve Bank of New Zealand's Policy Targets Agreements, which would allow for temporary breaches of the rules in the event of war, natural disaster and other severe supply shocks. Most aggregate demand shocks could be accommodated through the operation of the automatic stabilisers, without having to invoke a caveat to the rules.

The first fiscal rule would require the Commonwealth fiscal balance to be maintained within a range of +2 to -2 per cent of GDP on both an ex post and ex ante basis. A four percentage point range would have been sufficient to accommodate most of the cyclical variation in the budget balance we have seen in recent decades. The traditional objection to a budget balance rule is that it might force a poorly timed fiscal consolidation. This assumes that fiscal consolidations are necessarily contractionary, which need not be the case if expectations are appropriately managed.

The second rule would limit the net debt to GDP ratio to 10 per cent, which is above the average ratio for recent decades, although below the peak seen in the wake of the early 1990 recession. This would serve as a constraint on the ability of governments to run continuous budget deficits. It would also serve to tie down expectations in relation to the future path of net debt, which recent Intergenerational Reports have suggested will rise indefinitely beyond the current projection period on a "no policy change" basis. The 2007 report was honest enough to note that current policy settings "result in an unsustainable path for net debt towards the end of the projection period" (Commonwealth of Australia, 2007, p. xii), but this characterisation was dropped from the 2010 report (Commonwealth of Australia 2010). This projected path for net debt is potentially the most destabilising aspect of current fiscal policy settings from an expectations management perspective.

The third rule would cap the Commonwealth revenue and expenditure shares of GDP at 25 per cent. The current government has already undertaken to maintain the tax share of GDP below the level of 2007-2008, which was 23.6 per cent of GDP, according to the 2010-2011 Budget papers. Adding non-tax revenue of 1.4 per cent of GDP gave a revenue share of 25 per cent of GDP in 20072008, so the proposed rule would simply serve to codify and enforce an existing policy commitment. This would limit the size of government in relative terms, but not in absolute terms. To the extent that anchoring long-run fiscal expectations yields stronger economic growth, this can be expected to yield more resources for government for a given revenue share of GDP.

The parameters for these proposed rules are necessarily somewhat arbitrary, although they are designed to be consistent with the range of federal fiscal policy outcomes seen in recent decades, 
as well as existing policy commitments. The specific parameters for the rules are less important than the need for a well-defined fiscal policy framework that anchors long-run expectations, while allowing policy-makers to retain discretion over policy priorities within the chosen parameters. The fiscal policy choices made within that framework are then a matter for governments and the parliament to determine.

Enforcement problems have been a significant limitation on the effectiveness of fiscal policy rules in other countries. We propose an enforcement regime that would see the Fiscal Commission impose pecuniary penalties on all members of federal parliament for breaches of the rules not subject to one of the explicit caveats, as determined by the Commission. This would require cutting politicians' overall remuneration by 1 per cent for every one percentage point breach of each of the three policy rules. The pecuniary penalty is probably less significant than the loss of political reputation that would accompany the imposition of such penalties by an independent Commission. Unlike the existing Charter of Budget Honesty Act, any new fiscal responsibility legislation should be made subject to administrative and judicial review.

In summary, our proposed changes to Australia's fiscal responsibility legislation would assist politicians in better managing fiscal policy challenges such as demographic change and cycles in the terms of trade. The proposed fiscal policy rules would serve to tie down expectations in relation to long-run fiscal policy outcomes. The Fiscal Commission would provide for greater transparency and accountability in the conduct of fiscal policy and take some of the politics out of key aspects of the budget process.

\section{REFERENCES}

Ball, L. (1996), A Proposal for the Next Macroeconomic Reform, 11 November, Reserve Bank of New Zealand.

Carling, R. and Kirchner, S.. (2009), Fiscal Rules for Limited Government: Reforming Australia's Fiscal Responsibility Legislation, Policy Monograph 98. Centre for Independent Studies, Sydney.

Clarida, R., Gali, J. and Gertler, M. (1998), 'Monetary Policy Rules in Practice: Some International Evidence', European Economic Review, 42 (6), 1033-67.

Clarida, R., Gali, J. and Gertler, M. (1999), 'The Science of Monetary Policy: A New Keynesian Perspective', Journal of Economic Literature, 37, 1661-707.

Clarida, R., Gali, J. and Gertler, M. (2000), 'Monetary Policy Rules and Macroeconomic Stability: Evidence and Some Theory', Quarterly Journal of Economics, 115 (1), 147-80.

Commonwealth of Australia (2007), Intergenerational Report, April. Commonwealth of Australia, Canberra.

Commonwealth of Australia (2010), Australia to 2050: Future Challenges, January. Commonwealth of Australia, Canberra.

Cukierman, A. (1992), Central Bank Strategy, Credibility and Independence: Theory and Evidence. MIT Press, London.

Fleming, S. (2010), 'Heed the Advice of Fiscal Council', The Times, 13 September. Available at: http://www. theaustralian.com.au/business/markets/heed-the-advice-of-fiscal-council/story-e6frg926-1225920363185.

Gruen, N. (1997), 'Making Fiscal Policy Flexibly Independent of Government', Agenda, 4 (3), $297-307$.

von Hagen, J. (2002), 'Fiscal Rules, Fiscal Institutions, and Fiscal Performance', The Economic and Social Review, 33 (3), 263-84.

von Hagen, J. and Harden, I.J. (1995), 'Budget Processes and Commitment to Fiscal Discipline', European Economic Review, 39 (3), 771-9.

von Hagen, J. and Strauch, R. (2001), 'Formal Fiscal Restraints and Budget Processes as Solutions to a Deficit and Spending Bias in Public Finances - US Experience and Possible Lessons for EMU', ZEI Working Paper B14, Center for European Integration Studies.

Kirchner, S. (2006), 'Future Fund or Future Eater? The Opportunity Cost of Commonwealth Revenue Hoarding', Policy, 22 (3), 28-31.

Kirchner, S. (2007), 'Fiscal Policy and Interest Rates in Australia', Policy, 23 (3), 11-15.

Kocherlakota, N. and Phelan, C. (1999), 'Explaining the Fiscal Theory of the Price Level', Federal Reserve Bank of Minneapolis Quarterly Review, 33 (4), 14-23.

Leeper, E. (2009), 'Anchoring Fiscal Expectations', National Bureau of Economic Research Working Paper 15269, August. Available at: http://ideas.repec.org/p/nbr/nberwo/15269.html.

Leeper, E. (2010), Monetary Science, Fiscal Alchemy, Federal Reserve Bank of Kansas City Jackson Hole Symposium, 16 August, Jackson Hole, Wyoming.

Murray, A. (2008), Review of Operation Sunlight: Overhauling Budgetary Transparency, June. Commonwealth of Australia, Canberra.

Poterba, J.M. and von Hagen, J. (1999), Fiscal Institutions and Fiscal Performance. University of Chicago Press, Chicago. 